Çanakkale Onsekiz Mart University, Journal of Graduate School of Natural and Applied Sciences, 2019:5,1, 16-31

Araştırma / Research

\title{
Damla ve Toprak Altı Damla Sulamanın Mısır Verimi Üzerine Etkisi
}

\author{
Aslı Demirok ${ }^{1}$, Gökhan İsmail Tuylu ${ }^{2^{*}}$ \\ ${ }^{1}$ Harran Üniversitesi, Fen Bilimleri Enstitüsü, Tarımsal Yapılar ve Sulama ABD \\ ${ }^{2}$ Harran Üniversitesi, Ziraat Fakültesi, Tarımsal Yapılar ve Sulama Bölümü
}

11.04.2019 Geliş/Received, 03.05.2019 Kabul/Accepted

\section{Özet}

Harran Ovası koşullarına göre, 2016 yılında yürütülen çalışmada, mısır (Zea mays L. indendata) yetiştiriciliğinde farklı sulama uygulamaları içeren damla sulama sistemi (DSS) ve toprak altı damla sulama sistemi (TADSS)'nin karşılaştırılması amaçlanmıştır. Her iki sulama sisteminde sulama konular1; [ $\mathrm{I}_{1}(1.5), \mathrm{I}_{2}(1.25), \mathrm{I}_{3}(1.0), \mathrm{I}_{4}(0.75), \mathrm{I}_{5}(0.5)$ ] Class A Pan yöntemine göre belirlenmiş ve en uygun Class A Pan bitki katsayıları (Kcp) araştırılmıştır. Mısır için verim miktarı, sulama suyu miktarı (I), bitki su tüketimi (ET), su kullanımı (WUE) ve sulama suyu kullanım randımanı (IWUE) elde edilmiştir. Sulama suyu ve bitki su tüketimine göre tane verim ve bin tane verim değerleri analiz edilmiştir. Sonuç olarak, Kcp katsayısı her iki sulama sistemi için 1.25 olarak belirlenmiştir. Verim miktarları, DSS kullanılarak $698.4 \mathrm{~kg} \mathrm{da}^{-1}$ ile $1151.5 \mathrm{~kg} \mathrm{da}^{-1}$ arasında ve TADSS kullanılarak $705.4 \mathrm{~kg} \mathrm{da}^{-1}$ ile $1157.5 \mathrm{~kg} \mathrm{da}^{-1}$ arasında elde edilmiştir. Damla Sulama Sistemi ve TADSS ile uygulanan sulama suyu miktarı, konulara göre aynıdır ve 421.5 ile $1264.5 \mathrm{~mm}$ arasında değişmiştir. Bitki su tüketimi değerleri; DSS'ye göre 585.7 ile $1294.6 \mathrm{~mm}$ arasında, TADSS'ye göre 572.5 ile $1286.7 \mathrm{~mm}$ arasında belirlenmiştir. Su kullanımı (WUE) ve IWUE değerleri sırasıyla; DSS için $0.82-1.19 \mathrm{~kg} \mathrm{~m}^{-3}, 0.83-1.66 \mathrm{~kg} \mathrm{~m}^{-3}$ ve TADSS için $0.83-1.23 \mathrm{~kg} \mathrm{~m}^{-3}, 0.84-1.67 \mathrm{~kg} \mathrm{~m}^{-3}$ olarak hesaplanmıştır.

Anahtar Kelimeler: A-sınıfı buharlaşma kabı, killi toprak, lateral derinlik, Şanlıurfa

\section{Effect of Drip and Subsurface Drip Irrigation on Maize Yield}

\begin{abstract}
A study was carried out under the conditions of Harran Plain in 2016 to compare drip irrigation system (DIS) and subsurface drip irrigation system (SDIS) that contained different irrigation applications in cultivation of maize (Zea mays L. indendata). The irrigation treatment [I1 (1.5), I2 (1.25), I3 (1.0), I4 (0.75), I5 (0.5)] were determined according to Class A Pan method in both irrigation systems and optimum Class A Pan crop coefficients (Kcp) were investigated. The yield, the amount of irrigation water (I), the water consumption of plant (ET), the water use efficiency and the irrigation water use efficiency (WUE and IWUE) were obtained for maize. According to the irrigation water and the plant water consumption, the values of grain yield and 1000 grain yield were analyzed. As a result, the Kcp coefficient was determined as 1.25 for both irrigation systems. The yields were obtained to be between 698.4 and $1151.5 \mathrm{~kg} \mathrm{da}^{-1}$ by using DIS and they were obtained between 705.4 and $1157.5 \mathrm{~kg}$

*Sorumlu Yazar (Corresponding Author): Gökhan İsmail Tuylu

(e-posta:gokhantuylu@harran.edu.tr)

Bu makale Harran Üniversitesi Bilimsel Araştırmalar Koordinatörlüğü (HÜBAK) tarafindan desteklenen bir tez çalışması olup 16018 No'lu proje kapsamında yürütülmüsştür.
\end{abstract}


$\mathrm{da}^{-1}$ by using SDIS. According to the treatments, the amount of water applied by DIS and SSDIS were same and they changed between 421.5 and $1264.5 \mathrm{~mm}$. The plant water consumption values were between 585.7 and $1294.6 \mathrm{~mm}$ according to DIS and they were between 572.5 and $1286.7 \mathrm{~mm}$ according to SSDIS. The water use efficiency and IWUE values were calculated as $0.82-1.19 \mathrm{~kg} \mathrm{~m}^{-3}, 0.83-1.66 \mathrm{~kg} \mathrm{~m}^{-3}$ for DIS and $0.83-1.23 \mathrm{~kg} \mathrm{~m}^{-3}$, $0.84-1.67 \mathrm{~kg} \mathrm{~m}^{-3}$ for SSDIS respectively.

Keywords: class A pan, clay soil, lateral depth, Şanlıurfa

\section{Giriş}

Mısır dünyada ve ülkemizde yaygın olarak üretimi yapılan bitki deseni içerisindedir. Güneydoğu Anadolu Bölgesi'nde 2. ürün olarak ekilmesi yönünden önemlidir. Dünyada üretilen mısırların yaklaşık \%90'ı insanların ve hayvanların beslenmesinde kullanılmaktadır. Bunun \%65-70'i hayvan yemi olarak, \%20'si ise direkt olarak insanlar tarafindan tüketilmektedir. Geri kalan \%8-10'luk kısım ise, sanayide hammadde olarak değerlendirilmektedir (Anonim, 2017).

Mısır tarımının yapılabilmesi için yıllık yağışın ortalama 600-1200 mm kadar olması gerekmektedir. Ülkemizde yıllık yağgş miktarının ortalama $500-600 \mathrm{~mm}$ olduğu yerlerde dahi mısır yetiştirilebilmektedir. Ancak, böyle alanlarda sulama yoluyla yağış açığı giderilmelidir. Yağışların aralıklı ve önemli bir kısmının olgunlaşma devresinde olması gerekmektedir. $\mathrm{Bu}$ nedenle yaz yağışları mısır yetiştiriciliğinde büyük önem taşımaktadır (Şahin, 2001).

Mısırın suya önemli düzeyde ihtiyacı olduğu dönemler, püskül ve tane oluşumu dönemleridir. $\mathrm{Su}$ ihtiyacının karşılanmadığı durumda verimde azalmalar oluşur (Yıldırım ve ark., 1995). Mısırın sulanmasında özellikle bu dönemler gözetilerek sulama programları yapılır ve uygulanır. Kontrollü sulamanın yapılabildiği sistemler ise basınçlı sulama sistemleridir.

Basınçlı sulama sistemleri, dünyada ve ülkemizde gelişen sulama teknolojisine bağlı olarak hızla sulamada kullanılmak üzere yerini almıştır. Damla sulama sistemleri (DSS) su tasarrufu sağlayan, sulama işçiliğinde ve enerjide tasarruf sağlayan sistemlerdir. Toprak altı damla sulama sistemleri (TADSS) ise damla sulama sistemlerin bir modifikasyonudur. Dünyada ve ülkemizde sulama konusunda her iki sulama sistemi kullanılarak yapılan bilimsel çalışmalar yaygındır. Harran Ovası koşullarında; Kırnak ve ark.(2002), biberde damla ve toprak altı damla sulama uygulamaları gerçekleştirmişlerdir. Kırnak ve ark.(2003) ve Şimşek ve Gerçek (2005) tarafından, mısır sulamasında damla sulama sistemleri kullanılmış ve su-verim ilişkileri analiz edilmiştir.

Çalışmada, Harran Ovası koşullarında, 2016 yılında, damla ve toprak altı damla sulama sistemlerinin mısırın sulanmasında kullanılabilme olanakları araştırılmıştır. Verim miktarları, sulama suyu miktarı (I), bitki su tüketimi (ET), su kullanım ve sulama suyu kullanım randımanları (WUE ve IWUE) belirlenmiş ve her iki sulama sistemi için karşılaştırılmıştır. Sulama suyu ve bitki su tüketimine göre tane verim ilişkileri ve bin tane verim ilişkileri analiz edilmiştir. Bu çalışmada DSS ve TADSS koşullarında yetiştirilen mısır bitkisinin Kcp değeri yönünden karşılaştırılması amaçlanmıştır. Mısır konusunda çalışacak araştırmacılara, sulama koşullarının optimize edilmesi yönünden katkı sağlayacaktır. 


\section{Materyal ve Yöntem}

Çalışma, Harran Ovası'nda Şanlıurfa sınırları içerisinde Harran Üniversitesi uygulama alanında yürütülmüştür. Harran Ovası, coğrafik konum olarak denizden yüksekliği ortalama $465 \mathrm{~m}$ olup $37^{\circ} 08^{\prime} \mathrm{N}$ enlemi ve $38^{\circ} 46^{\prime}$ E boylamı arasındadır (Şekil 2.1).

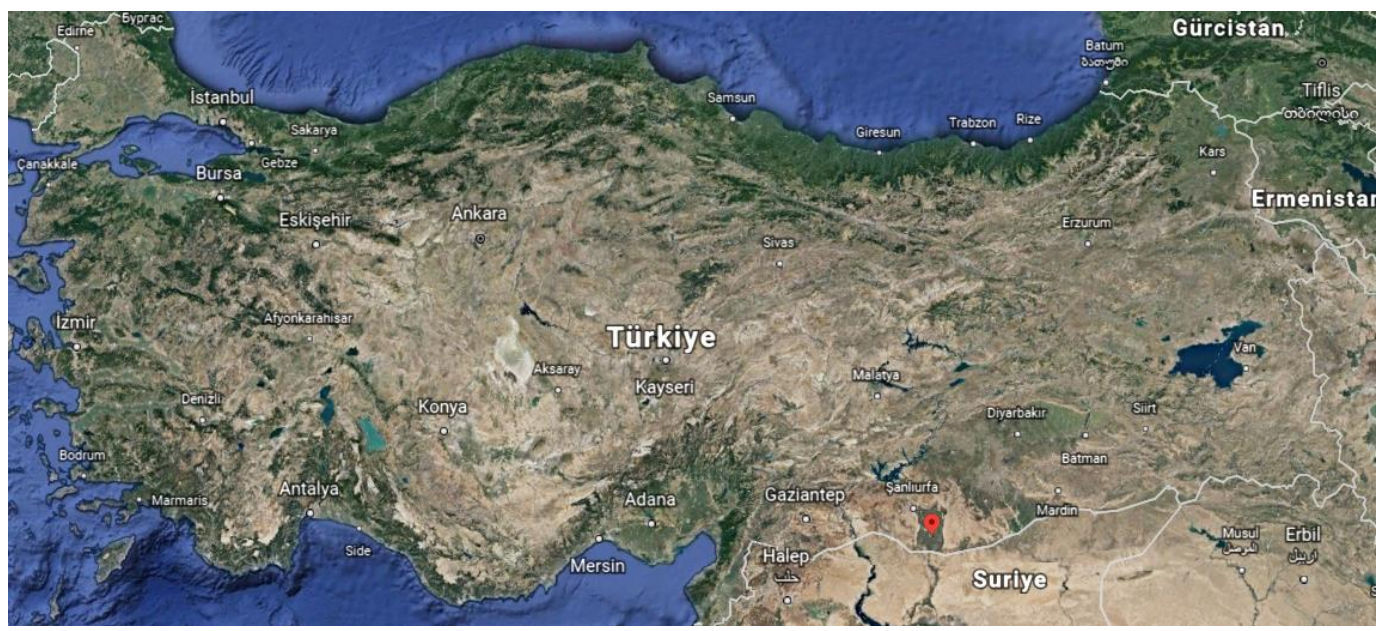

Şekil 2.1. Harran Ovası'nın coğrafik konumu (Anonim, 2019)

Şanlıurfa, Güneydoğu Anadolu iklim bölgesinde yer almakla beraber, Akdeniz ikliminin uzak etkisini de kısmen göstermektedir. Yazları sıcak ve kurak, kışları ise 1lık olan bir iklim özelliğine sahiptir. Çalışmanın yürütüldüğü 2016 yılında, mısırın ekim-hasat periyodu, ortalama sıcaklık değerleri 33.2-12.6 ${ }^{\circ} \mathrm{C}$ olarak gerçekleşmiştir. Deneme alanına ait bazı iklim parametreleri, 1985-2015 dönemine ait uzun yıllar ortalaması (UYO) ve 2016 yılı için, Çizelge 2.1'de sunulmuştur:

Çizelge 2.1. Deneme alanı bazı iklim parametreleri (Anonim, 2016)

\begin{tabular}{|c|c|c|c|c|c|c|c|c|}
\hline \multicolumn{2}{|c|}{$\begin{array}{l}\text { İklim } \\
\text { parametreleri }\end{array}$} & $\begin{array}{c}\text { Max. } \\
\text { Sicaklik }\end{array}$ & $\begin{array}{c}\text { Min. } \\
\text { Sicaklik }\end{array}$ & $\begin{array}{c}\text { Ort. } \\
\text { Sicaklik }\end{array}$ & $\mathrm{Nem}$ & $\begin{array}{c}\text { Rüzgâr } \\
\text { Hiz1 }\end{array}$ & $\begin{array}{l}\text { Güneşlenme } \\
\text { Süresi }\end{array}$ & Yağış \\
\hline Aylar & Y1l & $\left({ }^{\circ} \mathrm{C}\right)$ & $\left({ }^{\circ} \mathrm{C}\right)$ & $\left({ }^{\circ} \mathrm{C}\right)$ & $(\%)$ & $(\mathrm{m} / \mathrm{s})$ & (saat) & $(\mathrm{mm})$ \\
\hline \multirow{2}{*}{ Haziran } & 2016 & 42.0 & 18.9 & 29.8 & 28.0 & 1.9 & 11.9 & 0.6 \\
\hline & U.Y.O & 34.9 & 21.1 & 28.3 & 35.2 & 2.0 & 12.0 & 3.3 \\
\hline \multirow{2}{*}{ Temmuz } & 2016 & 43.0 & 20.9 & 33.0 & 25.4 & 1.9 & 12.4 & 0.2 \\
\hline & U.Y.O & 39.6 & 25.6 & 33.3 & 29.1 & 1.9 & 12.0 & 0.0 \\
\hline \multirow{2}{*}{ Ağustos } & 2016 & 43.0 & 21.2 & 33.2 & 30.6 & 1.6 & 11.1 & 0.0 \\
\hline & U.Y.O & 38.6 & 24.7 & 31.6 & 36.6 & 1.7 & 11.0 & 0.0 \\
\hline \multirow{2}{*}{ Eylül } & 2016 & 33.5 & 20.0 & 26.4 & 32.1 & 1.7 & 9.8 & 0.0 \\
\hline & U.Y.O & 35.2 & 22.1 & 27.9 & 35.2 & 1.7 & 9.1 & 0.3 \\
\hline \multirow{2}{*}{ Ekim } & 2016 & 33.9 & 12.3 & 22.1 & 35.9 & 1.2 & 8.6 & 22.0 \\
\hline & U.Y.O & 27.3 & 16.2 & 21.3 & 50.1 & 1.1 & 6.7 & 43.2 \\
\hline \multirow{2}{*}{ Kasım } & 2016 & 19.3 & 7.9 & 12.6 & 42.9 & 1.1 & 5.9 & 23.3 \\
\hline & U.Y.O & 19.4 & 9.2 & 13.3 & 54.2 & 1.2 & 5.8 & 17.4 \\
\hline
\end{tabular}


Harran Ovası toprakları ana materyali alüviyal ve derin profillidir. Profilin kireç ve potasyum oranı yüksek olup fosforca fakirdir. Toprak $\mathrm{pH}$ 's1 7.3-7.4 olup organik madde içeriği yüzeyden derine doğru azalan yapıdadır (\% 1.20 -\% 0.8) (Dinç ve ark., 1988). Deneme alanı toprakları killi bünyeli olup Harran Ovası koşularını temsil etmektedir (Çizelge 2.2).

Çizelge 2.2. Deneme alanı toprak özellikleri (Tarı, 2015)

\begin{tabular}{|c|c|c|c|c|c|c|c|c|c|}
\hline $\begin{array}{c}\text { Derinlik } \\
(\mathrm{cm})\end{array}$ & $\begin{array}{c}\text { Ec } \\
\left(\mathrm{dS} \mathrm{m}^{-1}\right)\end{array}$ & $\begin{array}{c}\mathrm{TK} \\
\left(\mathrm{g} \mathrm{g}^{-1}\right)\end{array}$ & $\begin{array}{c}\mathrm{SN} \\
\left(\mathrm{g} \mathrm{g}^{-1}\right)\end{array}$ & $\begin{array}{c}\text { As } \\
\left(\mathrm{g} \mathrm{cm}^{-3}\right)\end{array}$ & $\begin{array}{c}\text { Nem } \\
(\mathrm{mm})\end{array}$ & $\begin{array}{c}\text { Kil } \\
(\%)\end{array}$ & $\begin{array}{c}\text { Silt } \\
(\%)\end{array}$ & $\begin{array}{c}\text { Kum } \\
\%\end{array}$ & $\begin{array}{c}\text { Bünye } \\
\text { Sinıfi }\end{array}$ \\
\hline $0-30$ & 1.04 & 32.50 & 22.10 & 1.15 & 35.88 & 56.6 & 20.0 & 23.4 & $\mathrm{C}$ \\
\hline $30-60$ & 1.07 & 31.40 & 21.20 & 1.40 & 42.84 & 54.6 & 17.0 & 24.4 & $\mathrm{C}$ \\
\hline $60-90$ & 1.08 & 29.60 & 22.08 & 1.16 & 26.17 & 62.6 & 17.0 & 21.4 & $\mathrm{C}$ \\
\hline
\end{tabular}

C: Kil minerali

Bölgede sulama suyuna bağlı olarak yetiştiriciliği yapılan bitki deseni içerisinde ana ürün pamuk bitkisidir. Kışlık buğday yetiştirilen alanlarda yaz döneminde ikinci ürün olarak mısır ekilmektedir. Çalışmada, deneme materyali olarak PR32T83 mısır çeşidi kullanılmıştır.

Denemede kullanılan sulama suyu, kuyu suyu olup sulama suyu kalitesi olarak $\mathrm{C}_{3} \mathrm{~S}_{1}$ özelliğindedir. Sulama suyu tuzlu ve sodyum düzeyi düşüktür. Suyun $\mathrm{pH}$ değeri 7.0, elektriksel iletkenlik (EC) içeriği $1080 \mu \mathrm{mhos} \mathrm{cm}^{-1}$ 'dir (Çizelge 2.3).

Çizelge 2.3. Sulama suyunun bazı kimyasal özellikleri ( Şimşek, 2015)

\begin{tabular}{|c|c|c|c|c|c|c|c|c|c|c|}
\hline Elektriksel & \multicolumn{4}{|c|}{ Katyonlar $\mathrm{me} \mathrm{l}^{-1}$} & \multicolumn{4}{c|}{ Anyonlar me $\mathrm{l}^{-1}$} & \multirow{2}{\text{Ph}}{} & Sulama \\
\cline { 2 - 10 } iletkenlik & $\mathrm{Ca}^{++} \mathrm{Mg}^{++}$ & $\mathrm{K}^{+}$ & $\mathrm{Na}^{+}$ & $\begin{array}{l}\text { Top. } \\
\text { Total }\end{array}$ & $\mathrm{HCO}_{3}^{-}$ & $\mathrm{Cl}^{-}$ & $\mathrm{SO}^{--}$ & $\begin{array}{l}\text { Top. } \\
\text { Total }\end{array}$ & $\begin{array}{c}\text { degeri } \\
\text { suyu } \\
\text { sinıfi }\end{array}$ \\
\hline 1080 & 1.98 & 0.02 & 0.25 & 2.25 & 0.90 & 0.60 & 0.75 & 2.25 & 7.0 & $\mathrm{C}_{3} \mathrm{~S}_{1}$ \\
\hline
\end{tabular}

Çalışmada, istatistik analizler için MINİTAB16 paket programından yararlanılmıştır. Regresyon grafiklerinin belirlenmesinde ise EXCEL Microsoft Office programı kullanılmıştır.

Sulama suyu miktarları açık su yüzeyinden olan buharlaşma miktarı Class A Pan (A-sınıfı buharlaşma kabı) kullanılarak belirlenmiştir. Suyun ölçülü olarak uygulanmasında ise sayaç kullanılmıştır. Denemede sulama uygulamaları DSS ve TADSS kullanılarak yapılmıştır. Her iki sulama sistemi; ana boru hatt1, manifold boru hatt1, lateral, gübre tank1, elek filtre, manometre, sayaç ve bağlantı parçalarından oluşmaktadır. Lateraller $16 \mathrm{~mm}$ çapında olup $0.30 \mathrm{~m}$ damlatıcı aralığına sahiptir ve üzerinde $21 \mathrm{~h}^{-1}$ debili damlatıcılar bulundurmaktadır. İki sistem için de parsel hat başına $30 \mathrm{~mm}$ çaplı vanalar takılarak sulama suyu kontrollü uygulanmıştır. Lateraller, her bitki sırasına bir lateral gelecek şekilde $70 \mathrm{~cm}$ aralıklı olarak döşenmiştir. Toprak altı damla sulama sisteminde kullanılan lateral borular, toprak yüzeyinin $40 \mathrm{~cm}$ altına yerleștirilmiș özel tasarımlı borulardır. Bu sistemde, ana hat ve manifold borular deneme alanında toprak yüzeyine yerleştirilmiştir. Toprak altı damla sulama sisteminde, lateral hattı sonunda ek bir boru ilave edilerek sistemin kontrolü ve temizlenebilmesi sağlanmıştır. Ayrıca, sistemler üzerine yerleştirilen manometreler yardımıyla işletme basınçları izlenmiştir.

Araştırma, tesadüf blokları bölünmüş parseller deneme deseninde 3 tekerrürlü olarak yürütülmüştür. Deneme parselleri, $3.50 \times 3.00 \mathrm{~m}$ boyutlu $\left(10.5 \mathrm{~m}^{2}\right)$ olup mısır tohumları her bir sıra üzerinde, 13 adet bitki olacak şekilde, 5 sıralı ekilmiştir. Bitki sıra üzeri mesafe $18 \mathrm{~cm}$, 
sıra arası mesafe ise $70 \mathrm{~cm}$ 'dir. Sulama suyu miktarları Class A Pan buharlaşma kabına göre $\mathrm{I}_{1}(1.5), \mathrm{I}_{2}(1.25), \mathrm{I}_{3}(1.0), \mathrm{I}_{4}(0.75), \mathrm{I}_{5}(0.5)$ olarak belirlenmiş ve DSS ve TADSS kullanılarak uygulanmıştır.

Çalışmada, günlük buharlaşma miktarının belirlenmesinde açık su yüzeyinden olan buharlaşma esasına dayalı yöntem kullanılmıştır. Deneme alanının ortasına yerleştirilen Class A Pan buharlaşma kabı yardımıyla günlük buharlaşma miktarları ölçülmüştür (Kırnak ve ark., 2003; Şimşek ve Gerçek, 2005). Ölçümler her gün 17.00' da yapılmıştır. Buharlaşma kabı 5 günde bir temizlenmiştir. Çalışmada DSS ve TADSS ile uygulanacak sulama suyu miktarları (I) Class A Pan' dan ölçülen buharlaşma miktarı değerlerine bağlı olarak belirlenmiştir. Sulama suyunun miktarının hesaplanması, Kanber (1984)'e göre yapılmıştır. Uygulanacak sulama suyu miktarlarının belirlenmesinde aşağıdaki eşitlik kullanılmıştır:

$\mathrm{I}=\mathrm{A} \times \mathrm{K}_{\mathrm{cp}} \times \mathrm{E}_{\mathrm{p}} \times \mathrm{P}$

Eşitlikte kullanılan ifadeler;

$\mathrm{E}_{\mathrm{p}}$ : Class A Pan 'dan olan buharlaşma (mm),

I : Uygulanacak sulama suyu miktarı (1),

A : Pan kabı alanı $\left(\mathrm{m}^{2}\right)$,

P : Islatma alanı yüzdesi (Yıldırım, 2013),

$\mathrm{K}_{\mathrm{cp}}$ : Pan katsayıs1.

Deneme konularına uygulanan sulama suyu ve yağışlar kaydedilerek, bitki su tüketimi (evapotranspirasyon) değerleri su bütçesi eşitliği yardımıyla hesaplanmıştır (James, 1988). Derine sızma ve yüzey akış miktarlarının ihmal edilebilecek düzeyde olduğu (Demirel, 2012) kabul edilerek aşağıdaki eşitlik yardımıyla hesaplanmıştır:

$\mathrm{ET}=\mathrm{I}+\mathrm{P}-\mathrm{D}-\mathrm{R} \pm \Delta \mathrm{S}$

Eşitlikte kullanılan ifadeler;

ET: Bitki su tüketimi (mm),

I : Sulama suyu $(\mathrm{mm})$,

$\mathrm{P}:$ Yağış $(\mathrm{mm})$,

D : Derine sızma (mm),

$\mathrm{R}$ : Yüzey akış (mm),

$\Delta S$ : Bitki kök bölgesindeki su depolama farkı (mm)'nı ifade etmektedir.

Tane verimi $\left(\mathrm{kg} \mathrm{da}^{-1}\right)$; her parselden elde edilen tane verimlerinin dekardaki verime çevrilmesiyle elde edilmiştir. Bin tane ağırlı̆̆ (5 adet) elde edilen tanelerin, $(4 \times 100)$ 'e göre sayılıp tartılması ve 2.5 katsayısı ile çarpılmasıyla hesaplanmıştır (Şimşek ve Gerçek, 2005).

Su kullanım randımanı, sulama yöntemlerinin karşılaştırılmasında ve sulama programlarının değerlendirilmesinde kullanılan ölçütlerden birisidir (Tanner ve Sinclair, 1983). Ele alınan farklı sulama konuları ve sulama suyu kısıntılarının karşılaştırılarak en uygun sulama programının belirlenmesinde su kullanım ve sulama suyu randımanları değerlerinden yararlanılmıştır. Sudan yararlanma oranı olarak da ifade edilen su kullanım randımanı değerleri, her bir sulama konusuna ait elde edilen verimlerin, mevsimlik bitki su tüketimine 
oranı olarak ifade edilmektedir. Bu çalışmada su kullanım randımanı aşağıda verilen eşitlik kullanılarak hesaplanmıştır (Howell ve ark., 1990).

$\mathrm{WUE}=\mathrm{Ey} \times \mathrm{ET}^{-1}$

Eşitlikte kullanılan ifadeler;

WUE : Su kullanım randımanı $\left(\mathrm{kg} \mathrm{m}^{-3}\right)$,

Ey : Verim $\left(\mathrm{kg} \mathrm{da}^{-1}\right)$,

ET : Mevsimlik bitki su tüketimi (mm).

$\mathrm{IWUE}=\mathrm{Ey} \times \mathrm{I}^{-1}$

Eşitlikte;

IWUE = Sulama suyu kullanma randımanı $\left(\mathrm{kg} \mathrm{m}^{-3}\right)$,

I $\quad=$ Mevsimlik sulama suyu miktarı $(\mathrm{mm})$.

Deneme alanında kültivatörle 10-15 cm'lik derinlikte bir sürüm yapılmıştır. Daha sonra diskaro ile kesekler ufalandıktan sonra tapan çekilerek düzgün bir tohum yatağ 1 hazırlanmıştır. Toprak hazırlığı sonrası deneme desenine göre parselasyon işlemi yapılmıştır. Parselasyon işlemi; sıra arası $70 \mathrm{~cm}$, sıra üzeri $18 \mathrm{~cm}$ ve ekim derinliği $5-6 \mathrm{~cm}$ olacak şekilde düzenlenmiş ve 20 Haziran'da elle ekim işlemi yapılmıştır. Toprak hazırlığı sırasında 3-5 ton $\mathrm{da}^{-1}$ yanmış ahır gübresi, dikimle birlikte hesaplanan fosforlu gübrenin tamamı ve azotlu gübrenin yarısı uygulanmıştır. Azotlu gübrenin diğer yarısı ise ilk sulamadan önce verilmiştir. Deneme süresince, parsellerde gelişen yabancı otlar traktör ve el çapası ile sonraki dönemlerde parsel ve blok aralarında gelişen yabancı otlar ise el çapası ile temizlenmiş, ayrıca hastalık ve zararlıların denemenin sağlıklı yürütülmesini engelleyecek düzeyde zarar vermesi engellenmiştir. Başta koçan kurdu olmak üzere yaprak biti gibi zararlılara karşı kimyasal mücadele uygulanmıştır.

Tohum ekim işleminden 10 gün sonra mısır bitkilerinin çıkışı görülmüştür. Parselasyon işleminden önce bitki kök bölgesinin havalanması amacıyla bitki boyu 10-15 cm'ye ulaştı̆̆ında, birinci çapa yapılmış, sonra sıra üzeri $18 \mathrm{~cm}$ olacak şekilde el ile seyreltme yapılmıştır. Bitkiler 8-10 yapraklı olduğunda ikinci çapa ve boğaz doldurma işlemi yapılmıştır. Son olarak, hasattan önce kenar tesirleri çıkarılarak 15 Kasım 2016 tarihinde el ile hasat yapılmıştır.

\section{Bulgular ve Tartışma}

\subsection{Sulama Suyu Miktarlarına İlişkin Sonuçlar}

Misır tohumunun ekiminden deneme başlangıç tarihine kadar geçen periyotta (20 Haziran -15 Temmuz) her deneme parseline toplam $76 \mathrm{~mm}$ sulama suyu uygulanmıştır. Çalışmada, deneme konularının sulanmasına 15 Temmuz'da başlanmış ve 4 gün ara ile yapılmıştır. Damla sulama sistemi ve TADSS ile uygulanan sulama suyu miktarları aynı olup $1264.5 \mathrm{~mm}$ ile $421.5 \mathrm{~mm}$ arasında değişmiştir En fazla sulama suyu $I_{1}$ konusunda $(K c p=1.5)$, en az sulama suyu ise $\mathrm{I}_{5}(\mathrm{Kcp}=0.50)$ konusunda uygulanmıştır (Çizelge 3.1). 
Çizelge 3.1. Konulara göre, sulama suyu miktarları (mm)

\begin{tabular}{|l|c|c|c|c|c|}
\hline \multirow{2}{*}{} & \multicolumn{5}{|c|}{ Konular } \\
\cline { 2 - 6 } & $\mathrm{I}_{1}$ & $\mathrm{I}_{2}$ & $\mathrm{I}_{3}$ & $\mathrm{I}_{4}$ & $\mathrm{I}_{5}$ \\
\cline { 2 - 6 } $\begin{array}{l}\text { Sulama suyu } \\
\text { miktar1 }\end{array}$ & 1264.5 & 1053.8 & 843.0 & 632.3 & 421.5 \\
\hline
\end{tabular}

Kırnak ve ark. (2003), ardışık yıllar için mısırda $1215 \mathrm{~mm}$ ve $1295 \mathrm{~mm}$ sulama suyu uygulamışlardır. Şimşek ve Gerçek (2005) tarafından yapılan çalışmada, damla sulama ile gerçekleştirilen mısır sulanmasında sırasıyla; ilk yıl 814-1116 mm ve ikinci yıl 843-1206 mm sulama suyu miktarı uygulanmıştır.

\subsection{Bitki Su Tüketimine İlişkin Sonuçlar}

Damla sulama sistemi, bitki su tüketim değerleri ise sırasıyla; 1294.6, 1138.6, 945.1, 787.1 ve $585.7 \mathrm{~mm}$ olarak hesaplanmıştır. Damla sulama sisteminde en fazla bitki su tüketim $\mathrm{I}_{1}$ konusunda, en az bitki su tüketimi ise $\mathrm{I}_{5}$ konusunda gerçekleşmiştir. Toprak altı damla sulama sistemi bitki su tüketim değerleri sirasıyla; 1286.7, 1127.3, 934.3, 772.2 ve $572.5 \mathrm{~mm}$ olarak hesaplanmıştır. Toprak altı damla sulama sisteminde en fazla bitki su tüketimi $\mathrm{I}_{1}$ konusunda, en az bitki su tüketimi ise $I_{5}$ konusunda gerçekleşmiştir (Çizelge 3.2). Toprak altı damla sulama sistemi konularındaki bitki su tüketim değerleri DSS konularındaki bitki su tüketim değerlerine oranla daha az bulunmuştur (Şekil 3.1).

Çizelge 3.2. Sulama sistemlerine göre belirlenen bitki su tüketimi miktarları (mm)

\begin{tabular}{|c|c|c|c|c|c|}
\hline \multirow{2}{*}{$\begin{array}{c}\text { Sulama } \\
\text { Sistemleri }\end{array}$} & \multicolumn{5}{|c|}{ Deneme Konular1 } \\
\cline { 2 - 6 } & $\mathrm{I}_{1}$ & $\mathrm{I}_{2}$ & $\mathrm{I}_{3}$ & $\mathrm{I}_{4}$ & $\mathrm{I}_{5}$ \\
\hline DSS & 1294.6 & 1138.6 & 945.1 & 787.1 & 585.7 \\
\hline TADSS & 1286.7 & 1127.3 & 934.3 & 772.1 & 572.5 \\
\hline
\end{tabular}

Kırnak ve ark. (2003) tarafından, DSS ile gerçekleştirilen sulama uygulamalarında mısırın su tüketimini farklı yıllar için sırasıyla; $1320 \mathrm{~mm}, 1435 \mathrm{~mm}$ olarak belirlenmiştir. Şimşek ve Gerçek (2005) tarafından yapılan çalışmada ise mısırın bitki su tüketimi ardışık yıllar için sirasıyla; 909-1224 mm ve 923-1160 mm olarak elde edilmiş̧tir. 


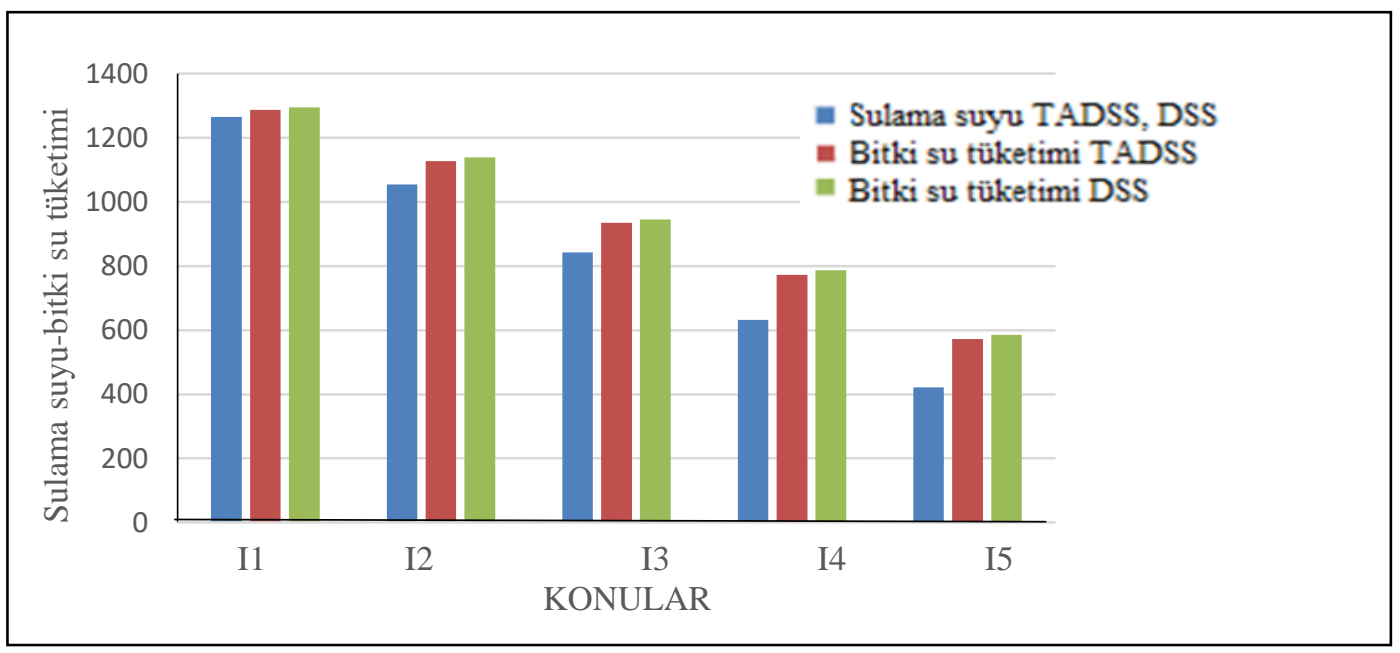

Şekil 3.1. DSS ve TADSS'ne göre mısırın bitki su tüketimi (mm)

\subsection{Mısır (Zea mays L. intendata)'ın Verim Miktarına İlişsin Sonuçlar}

Çalışmada farklı sulama uygulamalarına göre verim değerleri DSS'de 698.4-1055.2 $\mathrm{kg} \mathrm{da}^{-1}$, TADSS'de 705.4-1065.4 $\mathrm{kg} \mathrm{da}^{-1}$ olarak bulunmuştur. Farklı sulama sistemlerinin ve sulama düzeylerinin tane verimi üzerine etkileri incelendiğinde; sulama düzeyi konularında istatistiksel açıdan 0.01 önem düzeyinde bir farklılık bulunmuştur (Çizelge 3.3). Verim sonuçlarına bağlı olarak, mısırın yetiştirilmesinde her iki sulama sistemi için Kcp katsayısı 1.25 olarak belirlenmiştir.

Çizelge 3.3. Misır tane verimi varyans analizi

\begin{tabular}{|c|c|c|c|c|c|}
\hline $\begin{array}{c}\text { Varyasyon } \\
\text { Kaynağ1 }\end{array}$ & $\begin{array}{c}\text { Serbestlik } \\
\text { Derecesi }\end{array}$ & $\begin{array}{c}\text { Kareler } \\
\text { Toplamı }\end{array}$ & $\begin{array}{c}\text { Kareler } \\
\text { Ortalaması }\end{array}$ & F & P \\
\hline Sulama sistemi & 1 & 1822 & 1822 & 1.12 & 0.302 \\
\hline Sulama sistemi * Sulama Düzeyi & 4 & 215 & 54 & 0.03 & 0.998 \\
\hline Sulama Düzeyi & 4 & 559615 & 139904 & $86.18^{* *}$ & 0.000 \\
\hline Hata & 20 & 32467 & 1623 & & \\
\hline
\end{tabular}

*: \%5 düzeyinde önemli, **: \%1 düzeyinde önemli

Konular arasındaki farklılıklar ise Duncan one-way ANOVA testine göre değerlendirilmiştir (Çizelge 3.4). Tane verimi, sulama düzeyleri bakımından $705.9 \mathrm{~kg} \mathrm{da}^{-1}$ ile $1154.5 \mathrm{~kg} \mathrm{da}^{-1}$ arasında değişmiştir. Sulama düzeylerinde en yüksek tane verimi TADSS'de $1157.5 \mathrm{~kg} \mathrm{da}^{-1}$ ile $\mathrm{I}_{2}$ konusunda bulunurken, en düşük tane verimi DSS'de $698.4 \mathrm{~kg} \mathrm{da}^{-1}$ ile $\mathrm{I}_{5}$ konusundan elde edilmiştir. Sulama sistemleri arasında tane verimi ortalaması DSS'de $942.3 \mathrm{~kg} \mathrm{da}^{-1}$ ve TADSS' de $962.2 \mathrm{~kg} \mathrm{da}^{-1}$ olarak belirlenmiştir.

Çizelge 3.4. Duncan'a göre tane verim miktarının gruplandırılması $\left(\mathrm{kg} \mathrm{da}^{-1}\right)$

\begin{tabular}{|c|c|c|c|c|c|c|}
\hline \multirow{2}{*}{$\begin{array}{c}\text { Sulama } \\
\text { Sistemleri }\end{array}$} & \multicolumn{5}{|c|}{ Sulama Düzeyleri } & \multirow{2}{*}{ Ort. } \\
\cline { 2 - 7 } & $\mathrm{I}_{1}$ & $\mathrm{I}_{2}$ & $\mathrm{I}_{3}$ & $\mathrm{I}_{4}$ & $\mathrm{I}_{5}$ & $962.2 \mathrm{~A}$ \\
\hline TADSS & $1065.4 \mathrm{ab}$ & $1157.5 \mathrm{a}$ & $998.7 \mathrm{bc}$ & $883.8 \mathrm{c}$ & $705.4 \mathrm{de}$ & $962.3 \mathrm{~A}$ \\
\hline DSS & $1055.2 \mathrm{~b}$ & $1151.5 \mathrm{a}$ & $942.4 \mathrm{bc}$ & $864.2 \mathrm{~cd}$ & $698.4 \mathrm{e}$ & $942.3 \mathrm{c}$ \\
\hline Ort. & $1060.3 \mathrm{~B}$ & $1154.5 \mathrm{~A}$ & $970.6 \mathrm{C}$ & $874.0 \mathrm{CD}$ & $701.9 \mathrm{D}$ & \\
\hline
\end{tabular}

Not: Farklı harflerle gösterilen konu ortalamaları arasındaki fark önemlidir. 
Kırnak ve ark. (2003), farklı sulama uygulamalarına göre mısırda tane verimini $1294 \mathrm{~kg} \mathrm{da}^{-1}$ $405 \mathrm{~kg} \mathrm{da}^{-1}$ olarak belirlemişlerdir. Öktem ve Öktem (2009), mısır genotiplerinin çoğunda $1200 \mathrm{~kg} \mathrm{da}^{-1}$, in üzerinde tane verimi elde etmişlerdir.

Çalışmada farklı sulama uygulamalarına göre bin tane ağırlığı; DSS'de 301.2-195.7 g, TADSS'de ise 302.9-196.5 g olarak bulunmuştur. Farklı sulama sistemlerinin ve sulama düzeylerinin bin tane ağırlığı üzerine etkileri incelendiğinde; sulama düzeyi konularında istatistiksel açıdan 0.01 önem düzeyinde farklılık bulunmuştur (Çizelge 3.5).

Çizelge 3.5. Mısırın bin tane ağırlığına ilişkin varyans analiz sonuçları

\begin{tabular}{|c|c|c|c|c|c|}
\hline $\begin{array}{c}\text { Varyasyon } \\
\text { Kaynağ }\end{array}$ & $\begin{array}{c}\text { Serbestlik } \\
\text { Derecesi }\end{array}$ & $\begin{array}{c}\text { Kareler } \\
\text { Toplamı }\end{array}$ & $\begin{array}{c}\text { Kareler } \\
\text { Ortalamas } 1\end{array}$ & F & P \\
\hline Sulama sistemi & 1 & 32.0 & 32.0 & 0.06 & 0.815 \\
\hline Sulama sistemi * Sulama Düzeyi & 4 & 8.2 & 2.1 & 0.00 & 1.000 \\
\hline Sulama Düzeyi & 4 & 44696.8 & 11174.2 & $19.57 * *$ & 0.000 \\
\hline Hata & 20 & 11418.1 & 570.9 & \multicolumn{2}{|l}{} \\
\hline
\end{tabular}

*: \%5 düzeyinde önemli, **: \%1 düzeyinde önemli

Bin tane ağırlığının sulama düzeyleri bakımından 196.1 g ile 302.0 g arasında değişim gösterdiği belirlenmiştir. Sulama düzeylerinde en düşük bin tane ağırlığı DSS'de 195.7 g bulunurken, en yüksek bin tane ağırlığ 1 TADSS'de $302.9 \mathrm{~g}$ olarak elde edilmiştir. Sulama sistemleri arasında bin tane ağırlığı ortalama DSS'de $256.3 \mathrm{~g}$ ve TADSS'de $258.3 \mathrm{~g}$ olarak belirlenmiştir. Konular arasındaki farklılıklar ise Duncan'a göre belirlenmiştir (Çizelge 3.6).

Çizelge 3.6. Duncan’a göre bin tane ağırlık değerlerinin göre gruplandırılması (g)

\begin{tabular}{|c|c|c|c|c|c|c|}
\hline \multirow{2}{*}{ Sulama Sistemleri } & \multicolumn{5}{|c|}{ Sulama Düzeyleri } & \multirow{2}{*}{ Ort. } \\
\cline { 2 - 6 } & $\mathrm{I}_{1}$ & $\mathrm{I}_{2}$ & $\mathrm{I}_{3}$ & $\mathrm{I}_{4}$ & $\mathrm{I}_{5}$ & $258.3 \mathrm{~A}$ \\
\hline TADSS & $290.6 \mathrm{ab}$ & $302.9 \mathrm{a}$ & $267.5 \mathrm{ab}$ & $234.2 \mathrm{abc}$ & $196.5 \mathrm{c}$ & $258.3 \mathrm{a}$ \\
\hline DSS & $288.9 \mathrm{ab}$ & $301.2 \mathrm{ab}$ & $263.5 \mathrm{abc}$ & $232.2 \mathrm{bc}$ & $195.7 \mathrm{c}$ & $256.3 \mathrm{~A}$ \\
\hline Ort. & $289.8 \mathrm{~A}$ & $302.0 \mathrm{~A}$ & $265.5 \mathrm{AB}$ & $233.2 \mathrm{BC}$ & $196.1 \mathrm{C}$ & \\
\hline
\end{tabular}

Özcan (2010) tarafından, farklı mısır çeşitlerine göre bin tane ağırlığı en fazla 338 g ve en az 268 g olarak elde edilmiştir. Bin tane ağırlığı, Öktem ve Toprak (2013) tarafindan 397.5533.3 g, Durmuş (2015) tarafindan ise, 286.2-336.7 g olarak belirlenmiştir.

\subsubsection{Sulama Suyu-Tane Verimi İlişkisi}

Tane verimi ile uygulanan sulama suyu miktarları arasındaki ilişkileri tanımlayan su verim fonksiyonları incelenmiş ve aralarındaki ilişkiler belirlenmiştir (Şekil 3.2 ve 3.3). Sulama suyu miktarı artışına bağlı olarak tane verimi artmıştır. Ancak sulama suyunun miktarındaki artış belli bir seviyeden sonra tane veriminde azalmaya neden olmuştur. Çalışmada en fazla tane verimi, DSS ve TADSS için $\mathrm{I}_{2}$ sulama konusunda elde edilmiştir. Kara (2011) ve Okay ve Yazgan (2016)'a göre, sulama suyu ile mısırın tane verimi doğrusal ilişkilidir. 


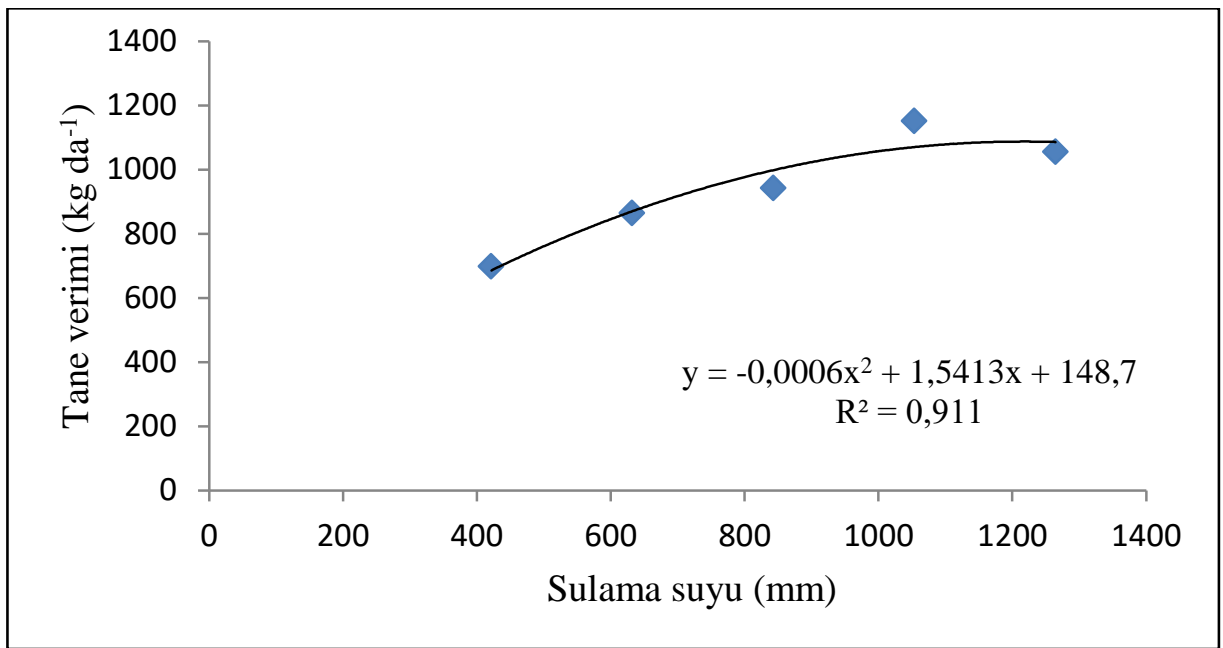

Şekil 3.2. DSS'e göre sulama suyu-tane verimi ilişkisi

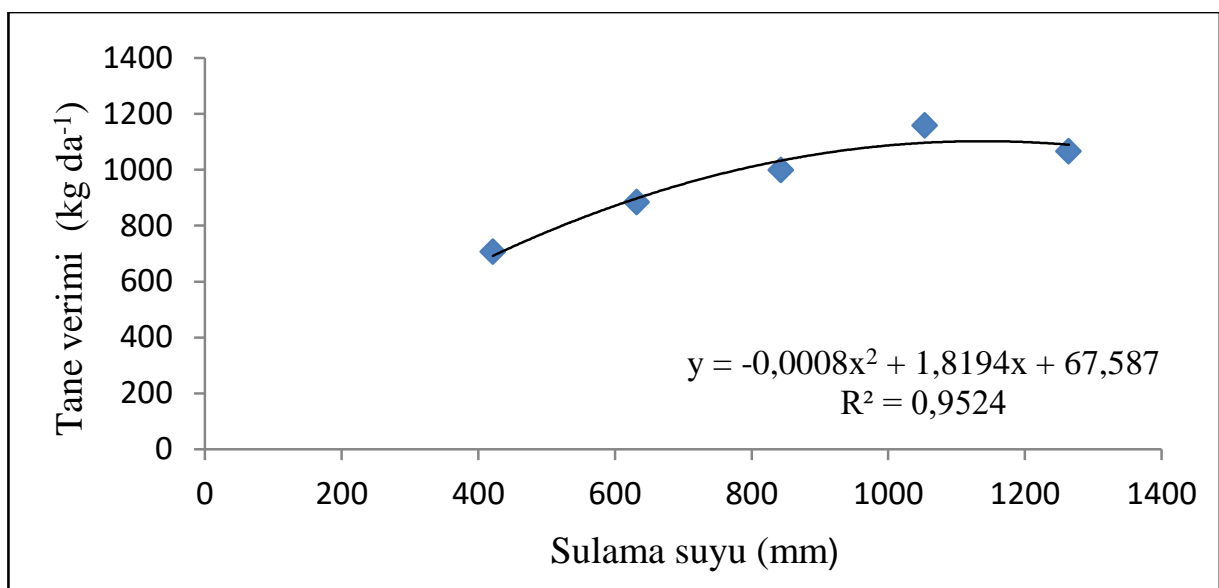

Şekil 3.3. TADSS'e göre sulama suyu-tane verimi ilişkisi

\subsubsection{Bitki Su Tüketimi-Tane Verimi İlişkisi}

Damla sulama sistemi ve toprak altı damla sulama sistemine göre, tane verimi ile mısırın su tüketimi arasındaki ilişkiler belirlenmiştir (Şekil 3.4 ve 3.5). Bitki su tüketimi ve mısırın tane verimi her iki sulama sistemi için doğrusal ilişkili olarak elde edilmiştir. Kara (2011) ve Okay ve Yazgan (2016)'e göre de damla sulama uygulamaları için tane verimi ve bitki su tüketimi doğrusal ilişkilidir.

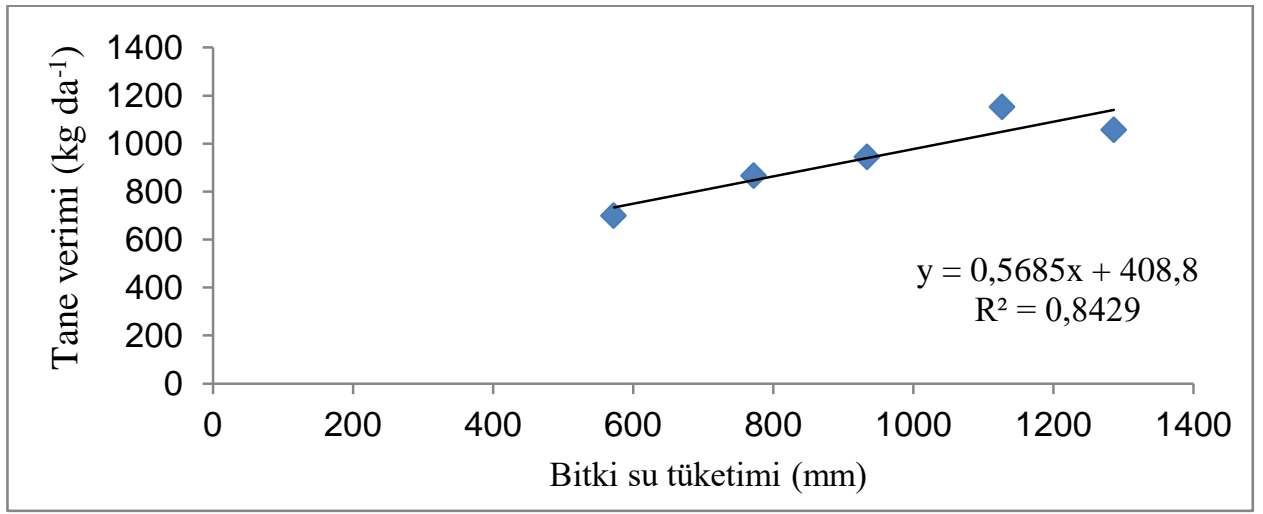

Şekil 3.4. DSS'e göre bitki su tüketimi- tane verimi ilişkisi 


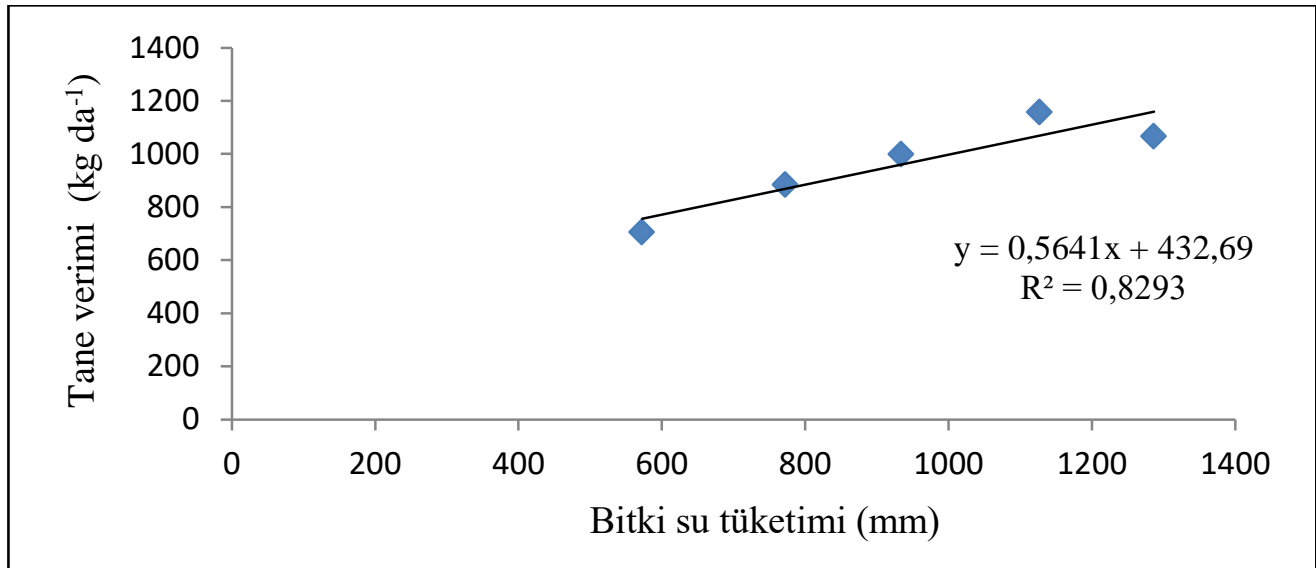

Şekil 3.5. TADSS'e göre bitki su tüketimi-tane verimi ilişkisi

\subsubsection{Sulama Suyu-Bin Tane Ağırlığı İlişkisi}

Her iki sulama sistemi için bin tane ağırlığı ve sulama suyu ilişkisi saptanmıştır. Sulama suyu miktarı ile mısırın bin tane ağırlığı arasında regresyon olarak güçlü bir iliş̧ki (DSS; $\mathrm{R}^{2}=$ 0,9639 ve TADSS; $\mathrm{R}^{2}=0,9691$ ) gözlemlenmiştir (Şekil 3.6 ve 3.7). Kara (2011), mısır için bin tane ağırlığı-sulama suyu ilişkisini istatistiksel yönden önemli $(\mathrm{P}<0.05)$ bulmuştur.

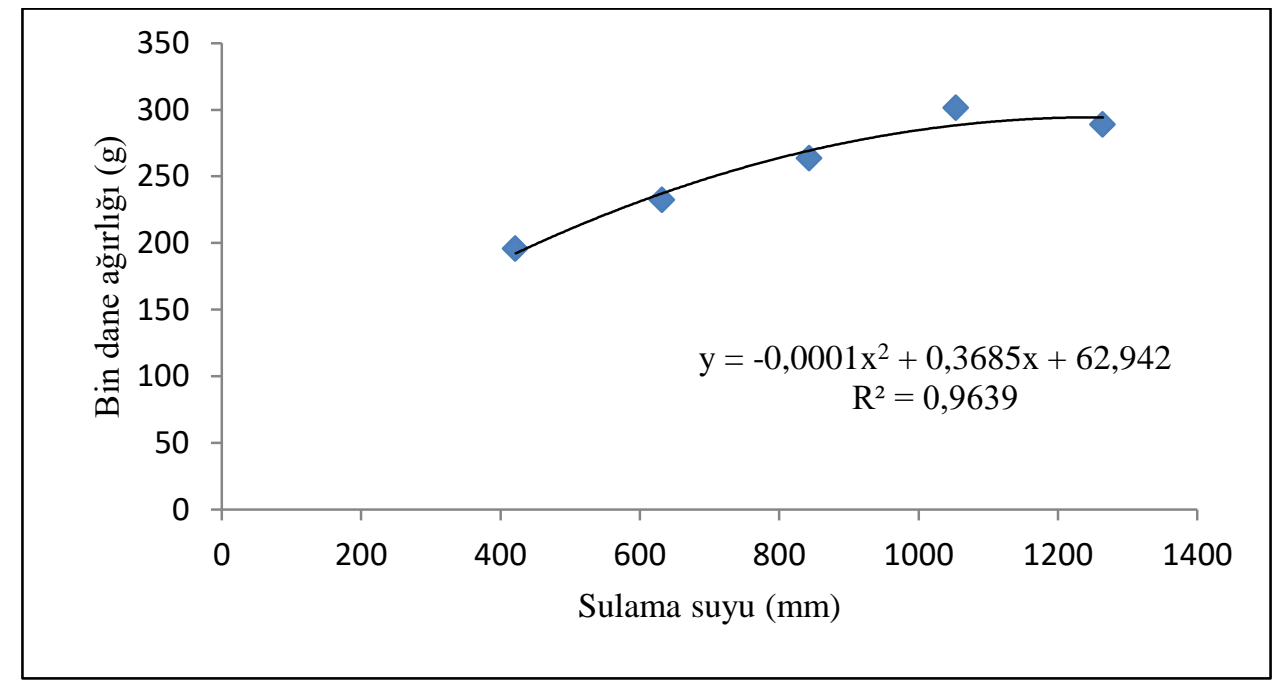

Şekil 3.6. DSS'e göre sulama suyu- bin tane ağırlığı ilişkisi

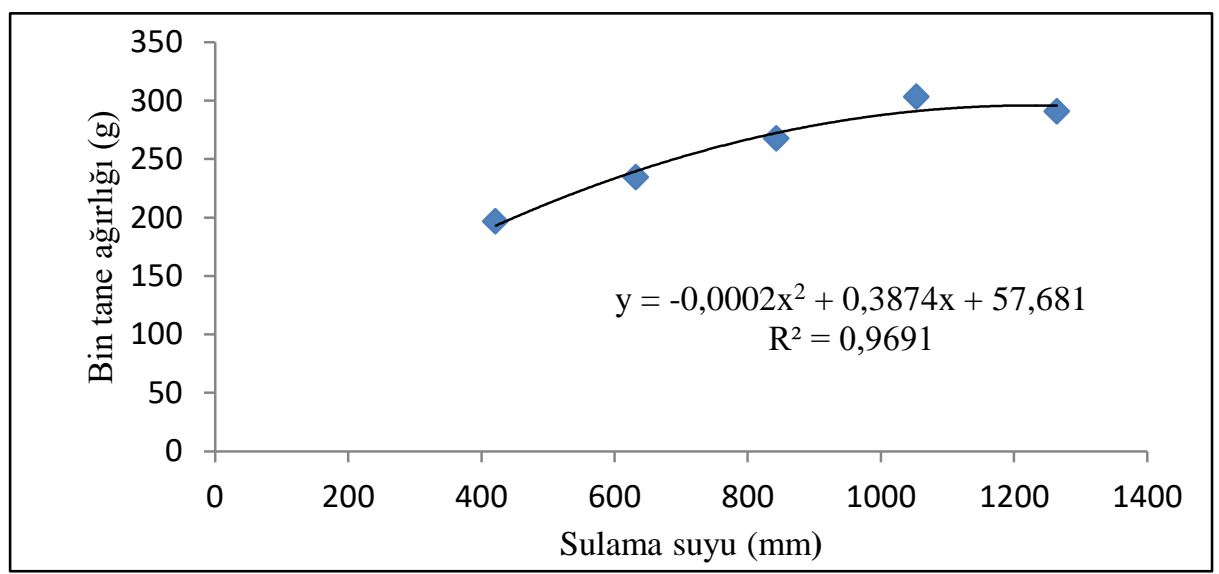

Şekil 3.7. TADSS'e göre sulama suyu-bin tane ağırlı̆̆ ilişkisi 


\subsubsection{Bitki Su Tüketimi - Bin Tane Ağırlığı İlişsisi}

Damla sulama sistemi ve toprak altı damla sulama sistemine göre bin tane ağırlıkları ile bitki su tüketimi arasındaki ilişskiler tanımlanmıştır. Her iki sulama sistemi için parametreler arasında doğrusal bir ilişki mevcuttur (Şekil 3.8 ve 3.9). Kara (2011), mısırın bin tane ağırlığı ile bitki su tüketimi arasındaki ilişkiyi istatistiksel olarak önemli $(\mathrm{P}<0.05)$ bulmuştur.

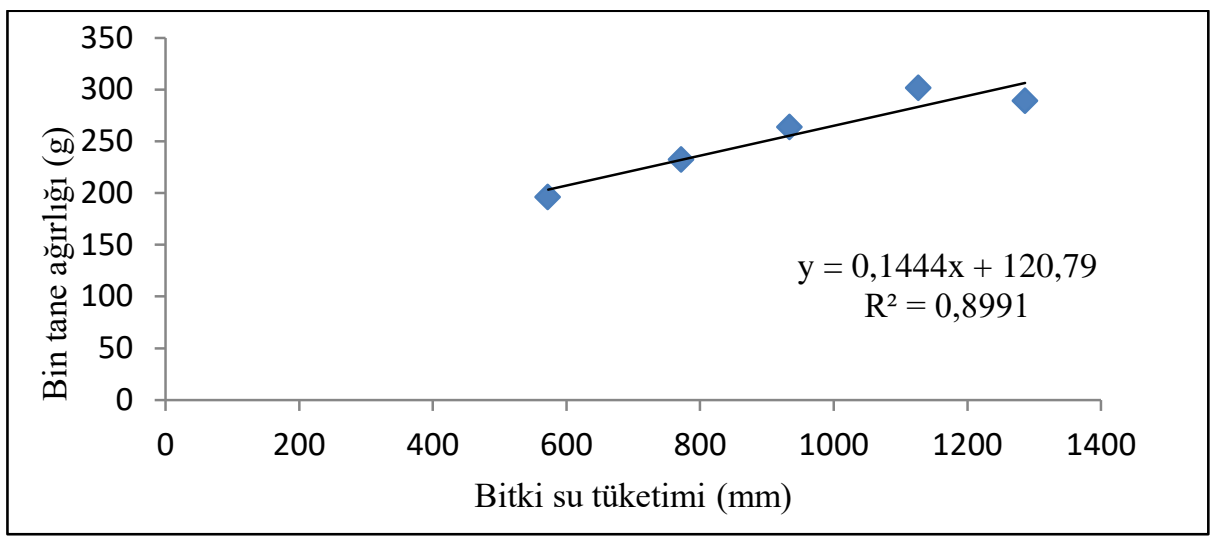

Şekil 3.8. DSS'e göre bin tane ağırlığ 1 - bitki su tüketimi ilişkisi

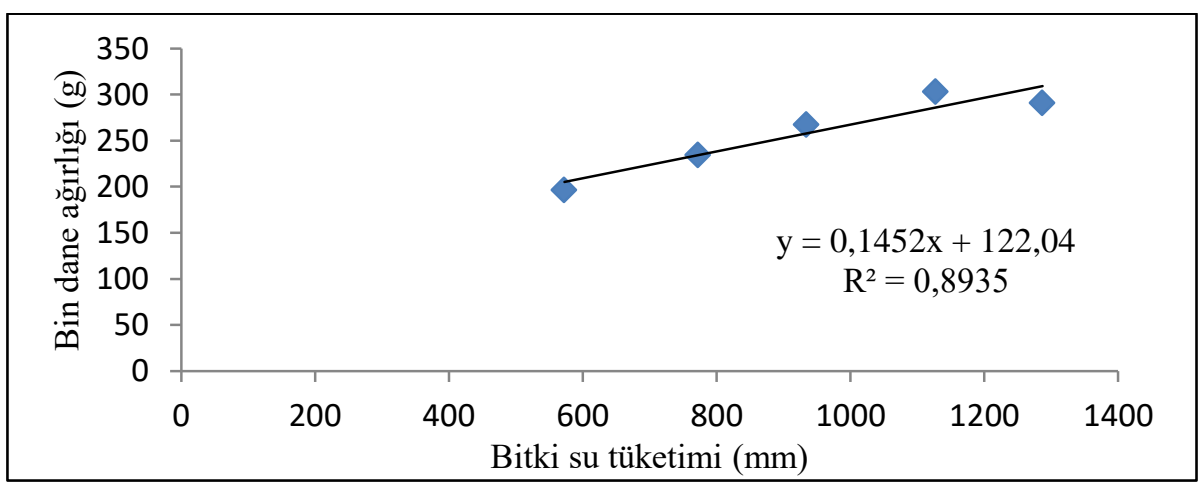

Şekil 3.9. TADSS'e göre bin tane ağırlığı-bitki su tüketimi ilişkisi

\subsection{Su Kullanım ve Sulama Suyu Kullanım Randımanı}

Damla sulama sistemi konularına ilişkin su kullanım randımanı 0.82-1.19 $\mathrm{kg} \mathrm{m}^{-3}$, sulama suyu kullanım randımanları ise $0.83-1.66 \mathrm{~kg} \mathrm{~m}^{-3}$ olarak bulunmuştur (Çizelge 3.7). Toprak altı damla sulama sistemine göre ise; su kullanım randımanı $0.83-1.23 \mathrm{~kg} \mathrm{~m}^{-3}$, sulama suyu kullanım randımanı 0.84-1.67 $\mathrm{kg} \mathrm{m}^{-3}$ olarak elde edilmiştir (Çizelge 3.8). Şimşek ve Gerçek (2005), sulama suyu kullanım randımanını 1.43-1.22 $\mathrm{kg} \mathrm{m}^{-3}$, su kullanım randımanını ise $1.02-1.13 \mathrm{~kg} \mathrm{~m}^{-3}$ olarak belirlemişlerdir

Çizelge 3.7. DSS'e göre su kullanım ve sulama suyu randımanları

\begin{tabular}{|c|c|c|c|c|c|}
\hline Konular & $\begin{array}{c}\mathrm{I} \\
(\mathrm{mm})\end{array}$ & $\begin{array}{c}\text { ET } \\
(\mathrm{mm})\end{array}$ & $\begin{array}{c}\text { Verim } \\
(\mathrm{kg} / \mathrm{da})\end{array}$ & $\begin{array}{c}\text { IWUE } \\
\left(\mathrm{kg} \mathrm{m}^{-3}\right)\end{array}$ & $\begin{array}{c}\text { WUE } \\
\left(\mathrm{kg} \mathrm{m}^{-3}\right)\end{array}$ \\
\hline $\mathrm{I}_{1}$ & 1264.5 & 1294.6 & 1055.2 & 0.83 & 0.82 \\
\hline $\mathrm{I}_{2}$ & 1053.8 & 1138.6 & 1151.5 & 1.09 & 1.01 \\
\hline $\mathrm{I}_{3}$ & 843 & 945.1 & 942.4 & 1.12 & 1.00 \\
\hline $\mathrm{I}_{4}$ & 632.3 & 787.1 & 864.2 & 1.37 & 1.10 \\
\hline $\mathrm{I}_{5}$ & 421.5 & 585.7 & 698.4 & 1.66 & 1.19 \\
\hline
\end{tabular}


Çizelge 3.8. TADSS'e göre su ve sulama suyu kullanım randımanları

\begin{tabular}{|c|c|c|c|c|c|}
\hline Konular & $\begin{array}{c}\mathrm{I} \\
(\mathrm{mm})\end{array}$ & $\begin{array}{c}\text { ET } \\
(\mathrm{mm})\end{array}$ & $\begin{array}{c}\text { Verim } \\
\left(\mathrm{kg} \mathrm{da}^{-1}\right)\end{array}$ & $\begin{array}{c}\text { IWUE } \\
\left(\mathrm{kg} \mathrm{m}^{-3}\right)\end{array}$ & $\begin{array}{c}\text { WUE } \\
\left(\mathrm{kg} \mathrm{m}^{-3}\right)\end{array}$ \\
\hline $\mathrm{I}_{1}$ & 1264.5 & 1286.7 & 1065.4 & 0.84 & 0.83 \\
\hline $\mathrm{I}_{2}$ & 1053.8 & 1127.3 & 1157.5 & 1.10 & 1.03 \\
\hline $\mathrm{I}_{3}$ & 843 & 934.3 & 998.7 & 1.18 & 1.07 \\
\hline $\mathrm{I}_{4}$ & 632.3 & 772.2 & 883.8 & 1.40 & 1.14 \\
\hline $\mathrm{I}_{5}$ & 421.5 & 572.5 & 705.4 & 1.67 & 1.23 \\
\hline
\end{tabular}

\section{Sonuç}

Harran Ovası'nda damla ve toprak altı damla sulama sistemleriyle uygulanan farklı sulama düzeylerine göre yetiştirilen mısırın verimi belirlenmiş, sulama suyu ve bitki su tüketimine göre tane verim ve bin tane verim ilişkileri elde edilmiştir. Su kullanım ve sulama kullanım randımanı hesaplanmıştır. Çalışmada; DSS ve TADSS kullanılarak, 4 gün ara ile, açık su yüzeyi buharlaşmasına bağlı olarak her bir sistem için 5 farklı sulama suyu miktarı; $\mathrm{I}_{1}(1.5), \mathrm{I}_{2}$ (1.25), $\mathrm{I}_{3}(1.0), \mathrm{I}_{4}(0.75), \mathrm{I}_{5}(0.5)$ uygulanmıştır. Damla sulama sistemi ve TADSS uygulama konularına göre en yüksek verim $\mathrm{I}_{2}$ konusundan elde edilmiştir. Her iki sulama sistemi için Kcp katsayıs1 1.25 olarak önerilmiştir. Damla sulama sistemi ile elde edilen verim miktarları $698.4 \mathrm{~kg} \mathrm{da}^{-1}$ ile $1151.5 \mathrm{~kg} \mathrm{da}^{-1}$ arasında, TADSS ile elde edilen verim miktarları ise $705.4 \mathrm{~kg}$ $\mathrm{da}^{-1}$ ile $1157.5 \mathrm{~kg} \mathrm{da}^{-1}$ arasında elde edilmiştir. Her iki sistem arasında verim yönünden istatistiksel olarak bir farka rastlanmamıştır. Damla sulama sistemi ve TADSS ile uygulanan sulama suyu miktarları, konulara göre aynı olup 421.5 ile $1264.5 \mathrm{~mm}$ arasında değişiklik göstermiştir. Damla sulama sistemine göre ET değerleri; 585.7 ile $1294.6 \mathrm{~mm}$ arasında, TADSS'ye göre 572.5 ile $1286.7 \mathrm{~mm}$ arasındadır. Damla sulama sistemi konularında, TADSS konularına oranla daha yüksek bitki su tüketimi elde edilmiştir. Su kullanımı ve IWUE değerleri DSS için sırasıyla; $0.82-1.19 \mathrm{~kg} \mathrm{~m}^{-3}, 0.83-1.66 \mathrm{~kg} \mathrm{~m}^{-3}$ ve TADSS için; $0.83-1.23 \mathrm{~kg}$ $\mathrm{m}^{-3}, 0.84-1.67 \mathrm{~kg} \mathrm{~m}^{-3}$ olarak hesaplanmıştır. En yüksek WUE ve IWUE değeri TADSS'nin $\mathrm{I}_{5}$ konusunda elde edilirken, en düşük değerler DSS'de $\mathrm{I}_{1}$ konusundan elde edilmiştir. Çalışmadaki bulgular doğrultusunda, mısır bitkisinin sulanmasında, her iki sulama sisteminin kullanılabileceği yetiştiricilere önerilmektedir. Aynı zamanda, mısır bitkisi üzerine her iki sulama sistemi için belirlenen Class A-Pan katsayısı diğer araştırmacılara katkı sağlayacaktır.

\section{Teşekkür}

Çalışma, Harran Üniversitesi Bilimsel Araştırmalar Koordinatörlüğü (HÜBAK) tarafından desteklenen bir tez çalışması olup 16018 No'lu proje kapsamında yürütülmüştür. Ekonomik desteklerinden dolayı teşekkürlerimizi sunarız. 


\section{Kaynakça}

Anonim, 2016. İklim Değerleri, Şanlıurfa Meteoroloji Bölge Müdürlüğü Şanlıurfa.

Anonim, 2017. Mısır Tarımı. 7 Haziran 2017, www.http.araștırma.tarım.gov.tr

Anonim, 2019. Harran Ovas1 06 May1s 2019, https://earth.google.com/web/search/

Demirel K., 2012. Toprak Altına Serilen Su Tutma Bariyerlerinin (stb) Toprak Su İçeriği ve Çim Bitkisi Gelişimi Üzerine Etkileri. ÇOMÜ Fen Bilimleri Enstitüsü, Toprak Anabilim Dal1, Doktora Tezi. 109 s.

Dinç U., Şenol S., Sayın M., Kapur S., Güzel N., Derici R., Yeşilsoy M. Ş., Yeğengil İ., Sarı M., Kaya Z., Aydın M., Kettaş F., Berkman A., Çolak A. K., Yılmaz K., Tunçgögüs B., Çavuşgil V., Özberk H., Gülüt K. Y., Karaman C., Dinç O., Öztürk N., Kara E.E., 1988. Güneydoğu Anadolu Bölgesi Toprakları. (GAT): I. Harran Ovası. TÜBİDAK Tarım ve Ormancılık Araştırma Grubu Güdümlü Araştırma Projesi Kesin Raporu. TOAG, Proje No: 534, Adana.

Durmuş E., 2015. Bazı Mısır Çeşitlerinin Tarla Koşullarında Su Kullanım Etkinliklerinin Belirlenmesi ve İlişkili Fizyolojik Parametrelerin İncelenmesi. Yüksek Lisans Tezi, Ege Üniversitesi, Fen Bilimleri Enstitüsü, İzmir.

Howell T. A., Cuenca R. H., Solomon K. H., 1990. Crop Yield Response. Manamegent of Farm Irrigation Systems. ASAE, 2p.

James L.G., 1988, Principles of Farm Irrigation Systems Design. John Wiley and Sons. Inc. New York, 543s.

Kanber R., 1984. Çukurova Koşullarında Açık Su Yüzeyi Buharlaşmasından Yararlanarak Birinci ve İkinci Ürün Yerfıstığının Sulanması Bölge Topraksu Arşt. Enst. Yay. 114 (64), Tarsus, 93.

Kara S., 2011. Konya Ekolojik Koşullarında Damla Sulama Yöntemi ile Sulanan Mısır Bitkisinde Su-Verim İlişkileri. Selçuk Üniversitesi, Yüksek Lisans Tezi, Fen Bilimleri Enstitüsü, Konya.

Kırnak H., Kaya C., Değirmenci V., 2002. Growth and Yield Parameters of Bell Peppers with Surface and Subsurface Drip Irrigation Systems Under Different Irrigation Levels. Atatürk Üniversitesi, Ziraat Fakültesi Dergisi, 33 (4): 383-389. 
Kırnak H., Gençoğlan C., Değirmenci V., 2003. Harran Ovası Koşullarında Kısıntılı Sulamanın II. Ürün Mısır Verimine ve Bitki Gelişimine Etkisi. Atatürk Üniversitesi Ziraat Fakültesi Dergisi, 34(2): 117-123.

Okay D., Yazgan S., 2016. Farklı Su Uygulama Düzeylerinin Mısır Bitkisi Verimi Üzerine Etkisi. Uludağ Üniversitesi Ziraat Fakültesi Dergisi, 30(1): 1-1

Öktem A., Öktem A.G., 2009. Bazı At dişi Hibrit Mısır (Zea mays L. indentata) Genotiplerinin Harran Ovası Koşullarında Performanslarının Belirlenmesi. Harran Üniversitesi Ziraat Fakültesi Dergisi, 13(2): 49-58.

Öktem A., Toprak A., 2013. Çukurova Koşullarında Bazı Atdişi Mısır (Zea Mays L. indentata) Genotiplerinin Verim ve Morfolojik Özelliklerinin Belirlenmesi. Harran Tarım ve Gida Bilimleri Dergisi, 17(4): 15-24.

Özcan G., 2010. Mısır Çeşitlerinin Kısıntılı Su Uygulamalarına Tepkilerinin Belirlenmesi. Yüksek Lisans Tezi, Selçuk Üniversitesi, Fen Bilimleri Enstitüsü, Konya.

Şahin S., 2001. Türkiye'de Mısır Ekim Alanlarının Dağılışı ve Mısır Üretimi, Gazi Üniversitesi Gazi Eğitim Fakültesi Dergisi, 21(1): 73-90.

Şimşek M., 2015. Harran Üniversitesi Ziraat Fakültesi Tarımsal Yapılar ve Sulama Bölümü Yaz Stajı Ders Notları (basılmamış), Şanlıurfa.

Şimşek M., Gerçek S., 2005. Yarı Kurak Koşullarda Damla Sulamada Farklı Sulama Aralıklarının Mısır Bitkisinin (Zea mays L. indentata) Su Verim İlişkilerine Etkisi. Atatürk Üniversitesi Ziraat Fakültesi Dergisi, 36(1): 77-82.

Tanner O.B., Sinclair T.R., 1983. Efficient Water Use in Crop Prodution; Research Limitation to Efficent Water Use in Crop Production. ASA; CSSA, SSSA Pub., pp. 1-25, Madison, Wiskonsin.

Tarı A.F., 2015. Deneme Alanı Topraklarının Bazı Fiziksel ve Kimyasal Özellikleri. Harran Üniversitesi Ziraat Fakültesi Tarımsal Yapılar ve Sulama Bölümü. Yaz Staj1 Ders Notları (basılmamış), Şanlıurfa.

Yıldırım O., Kodal S., Selenay M.F., Yıldırım E., 1995. Kısıntılı Sulamanın Verime Etkisi, 5. Ulusal Kültürteknik Kongresi Bildirileri Kitab1, Antalya, 347-365. 
Y1ldırım O., 2013. Sulama Sistemlerinin Tasarımı. Ankara Üniversitesi Ziraat Fakültesi Yayınları, yayın no: 1594, Ders kitabı: 546, 367s, Ankara. 